\title{
Lutibacter maritimus sp. nov., isolated from a tidal flat sediment
}

\author{
Sooyeon Park, So-Jung Kang, Tae-Kwang Oh and Jung-Hoon Yoon
}

Correspondence

Jung-Hoon Yoon

jhyoon@kribb.re.kr
Korea Research Institute of Bioscience and Biotechnology (KRIBB), PO Box 115, Yusong, Taejon, Republic of Korea

\begin{abstract}
A Gram-staining-negative, aerobic, non-motile, non-gliding, yellow-pigmented and rod-shaped bacterial strain, designated $\mathrm{S} 7-2^{\top}$, was isolated from a tidal flat sediment at Saemankum on the west coast of Korea and investigated using a polyphasic taxonomic approach. Strain S7-2 ${ }^{\top}$ grew optimally at $\mathrm{pH} 7.0-8.0$, at $25-30{ }^{\circ} \mathrm{C}$ and in the presence of $2 \%(\mathrm{w} / \mathrm{v}) \mathrm{NaCl}$. Phylogenetic analyses based on $16 \mathrm{~S}$ rRNA gene sequences showed that strain S7-2 ${ }^{\top}$ clustered with Lutibacter litoralis CF-TF09 ${ }^{\top}$, a member of the family Flavobacteriaceae, with which it showed $95.8 \% 16 \mathrm{~S}$ rRNA gene sequence similarity. It contained MK-6 as the predominant menaquinone and iso- $\mathrm{C}_{15: 0}$ and $\mathrm{C}_{15: 1} \omega 6 \mathrm{c}$ as the major fatty acids. The major polar lipids of strain $\mathrm{S} 7-2^{\top}$ and L. litoralis JCM $13034^{\top}$ were phosphatidylethanolamine and three unidentified lipids. The DNA $\mathrm{G}+\mathrm{C}$ content was $34.6 \mathrm{~mol} \%$. Differential phenotypic properties and phylogenetic distinctiveness suggested that strain $S 7-2^{\top}$ represents a novel species of the genus Lutibacter, for which the name Lutibacter maritimus sp. nov. is proposed. The type strain is $57-2^{\top}(=$ KCTC $22635^{\top}=$ CCUG $57524^{\top}$ ).
\end{abstract}

The genus Lutibacter, a member of the family Flavobacteriaceae (Bernardet et al., 1996, 2002; Bernardet \& Nakagawa, 2006) of the phylum Bacteroidetes, comprises a single recognized species, Lutibacter litoralis (Choi \& Cho, 2006). In this study, we describe a bacterial strain, designated $\mathrm{S} 7-2^{\mathrm{T}}$, which was isolated from a tidal flat sediment on the west coast of Korea. Comparative $16 \mathrm{~S}$ rRNA gene sequence analysis indicated that strain $S 7-2^{\mathrm{T}}$ was phylogenetically most closely affiliated to the genus Lutibacter. The aim of the work was to determine the exact taxonomic position of strain $\mathrm{S} 7-2^{\mathrm{T}}$ by using a polyphasic taxonomic approach.

Strain $\mathrm{S} 7-2^{\mathrm{T}}$ was isolated by the dilution-plating technique on marine agar 2216 (MA; Difco) at $25^{\circ} \mathrm{C}$. L. litoralis JCM $13034^{\mathrm{T}}$ was used as a reference strain for phenotypic characterization and polar lipid analysis. The morphological, physiological and biochemical characteristics of strain $\mathrm{S} 7-2^{\mathrm{T}}$ were investigated by using routine cultivation on MA at $30{ }^{\circ} \mathrm{C}$. Growth at 4, 15, 20, 25, 30, 37, 40 and $45{ }^{\circ} \mathrm{C}$ was measured on MA. Growth with various $\mathrm{NaCl}$ concentrations $(0.5 \%, \mathrm{w} / \mathrm{v}$, and $1.0-12.0 \%, \mathrm{w} / \mathrm{v}$, in increments of $1.0 \%$ ) was measured in marine broth 2216 (MB; Difco) and trypticase soy broth (TSB; Difco). Growth in the absence of $\mathrm{NaCl}$ was investigated by using TSB prepared according to the formula of the Difco medium except that $\mathrm{NaCl}$ was excluded and supplemented with $0.45 \%(\mathrm{w} / \mathrm{v}) \mathrm{MgCl}_{2} \cdot 6 \mathrm{H}_{2} \mathrm{O}$ or $0.06 \%$ (w/v) KCl. The $\mathrm{pH}$

The GenBank/EMBL/DDBJ accession number for the $16 \mathrm{~S}$ rRNA gene sequence of strain S7-2 ${ }^{\top}$ is FJ598048. range for growth was determined in $\mathrm{MB}$ adjusted to $\mathrm{pH} 4.5-9.5$ (in increments of $0.5 \mathrm{pH}$ unit) by the addition of $\mathrm{HCl}$ or $\mathrm{Na}_{2} \mathrm{CO}_{3}$. The $\mathrm{pH}$ values were verified after autoclaving. Growth under anaerobic conditions was determined after incubation in a Forma anaerobic chamber on MA and on MA supplemented with $0.1 \%(\mathrm{w} / \mathrm{v})$ potassium nitrate, both of which had been prepared anaerobically under a nitrogen atmosphere. Cell morphology was examined by using light microscopy (E600; Nikon) and transmission electron microscopy (CM-20; Philips). Flagellation was determined by using transmission electron microscopy with cells from an exponentially growing culture. For this purpose, the cells were negatively stained with $1 \%(\mathrm{w} / \mathrm{v})$ phosphotungstic acid and the grids were examined after being air-dried. Gliding motility was investigated as described by Bowman (2000).

The Gram reaction was determined by using the bioMérieux Gram-stain kit according to the manufacturer's instructions. Catalase and oxidase activities were determined as described by Cowan \& Steel (1965). Hydrolysis of casein, starch, Tween 80 and tyrosine were performed on MA, using the substrate concentrations described by Cowan \& Steel (1965). Hydrolysis of aesculin, gelatin and urea and reduction of nitrate were investigated as described by Lányí (1987) with the modification that artificial seawater (containing per litre distilled water: $23.6 \mathrm{~g} \mathrm{NaCl}, 0.64 \mathrm{~g} \mathrm{KCl}, 4.53 \mathrm{~g} \mathrm{MgCl}_{2} .6 \mathrm{H}_{2} \mathrm{O}, 5.94 \mathrm{~g}$ $\mathrm{MgSO}_{4} \cdot 7 \mathrm{H}_{2} \mathrm{O}, 1.3 \mathrm{~g} \mathrm{CaCl} 2.2 \mathrm{H}_{2} \mathrm{O}$; Bruns et al., 2001) was used for the preparation of media. Cellulase and xylanase activities were investigated on MA containing 
$0.5 \%$ CM-cellulose (Sigma) and xylan (Sigma), respectively, and detected according to the method of Teather \& Wood (1982). DNase activity was examined by using DNase test agar with methyl green (Difco) with the modification that artificial seawater was used for the preparation of the medium. Acid production from carbohydrates was determined as described by Leifson (1963). Utilization of substrates as sole carbon and energy sources was tested as described by Baumann \& Baumann (1981), using supplementation with $2 \%$ (v/v) Hutner's mineral base (Cohen-Bazire et al., 1957) and $1 \%(\mathrm{v} / \mathrm{v})$ vitamin solution (Staley, 1968). $\mathrm{H}_{2} \mathrm{~S}$ production was tested as described by Bruns et al. (2001).

Susceptibility to antibiotics was investigated on MA plates by using antibiotic discs containing the following ( $\mu \mathrm{g}$ per disc unless otherwise stated): polymyxin B (100 U), streptomycin (50), penicillin G (20 U), chloramphenicol (100), ampicillin (10), cephalothin (30), gentamicin (30), novobiocin (5), tetracycline (30), kanamycin (30), lincomycin (15), oleandomycin (15), neomycin (30) and carbenicillin (100). Enzyme activities were determined by using the API ZYM system (bioMérieux) incubated for $4 \mathrm{~h}$ at $30{ }^{\circ} \mathrm{C}$. Additional biochemical tests were performed using the API 20E system (bioMérieux); strips were inoculated with cells suspended in artificial seawater. The presence of flexirubin-type pigments was investigated as described by Reichenbach (1992). For pigment-absorption spectrum analysis, strain $\mathrm{S} 7-2^{\mathrm{T}}$ was cultivated aerobically in the dark at $30{ }^{\circ} \mathrm{C}$ in $\mathrm{MB}$. The culture was centrifuged, washed twice using a MOPS buffer $(0.01 \mathrm{M}$ MOPS/NaOH, $\left.0.1 \mathrm{M} \mathrm{KCl}, 0.001 \mathrm{M} \mathrm{MgCl}_{2} ; \mathrm{pH} 7.5\right)$ and disrupted by sonication with a Branson Sonifier 450. After removal of cell debris by centrifugation, the absorption spectrum of the supernatant was examined on a Beckman Coulter DU800 spectrophotometer.

Strain $57-2^{\mathrm{T}}$ was cultivated for 3 days in $\mathrm{MB}$ at $30{ }^{\circ} \mathrm{C}$ to obtain the cell biomass required for DNA extraction and for the analysis of isoprenoid quinones and polar lipids. $L$. litoralis JCM $13034^{\mathrm{T}}$ was cultivated under the same conditions for polar lipid analysis. Isoprenoid quinones were analysed as described by Komagata \& Suzuki (1987), using reversed-phase HPLC and a YMC ODS-A $(250 \times 4.6 \mathrm{~mm})$ column. Polar lipids were extracted according to the procedures described by Minnikin et al. (1984) and identified by two-dimensional TLC followed by spraying with appropriate detection reagents (Minnikin et al., 1984; Komagata \& Suzuki, 1987). For cellular fatty acid analysis, cell mass of strain $\mathrm{S} 7-2^{\mathrm{T}}$ and $L$. litoralis JCM $13034^{\mathrm{T}}$ was harvested from MA plates after cultivation for 2 days at $30{ }^{\circ} \mathrm{C}$. The fatty acids were extracted and fatty acid methyl esters were prepared according to the standard protocol of the MIDI/Hewlett Packard Microbial Identification System (Sasser, 1990). The DNA G+C content was determined using the method of Tamaoka \& Komagata (1984) with the modification that DNA was hydrolysed using nuclease P1 (Sigma) and the resultant nucleotides were analysed by a reversed-phase HPLC
Table 1. Differential phenotypic characteristics of strain $S 7-2^{\top}$ and $L$. litoralis JCM $13034^{\top}$

Data are taken from this study and Choi \& Cho (2006) unless otherwise stated. Both strains are Gram-staining-negative, non-motile, nongliding and rod-shaped. Both strains are positive for catalase, hydrolysis of aesculin, DNA and gelatin, for acid production from D-galactose, Dglucose, D-mannose, cellobiose and lactose, for activity of alkaline phosphatase, esterase lipase (C8) and leucine arylamidase and for susceptibility to carbenicillin, chloramphenicol, lincomycin and oleandomycin. Both strains are negative for anaerobic growth, for oxidase, for production of indole and $\mathrm{H}_{2} \mathrm{~S}$ (this study), for nitrate reduction, for hydrolysis of $\mathrm{CM}$-cellulose (this study), tyrosine (this study), urea and xylan (this study), for acid production from myoinositol, D-mannitol, D-sorbitol, L-arabinose, melezitose, melibiose, raffinose, L-rhamnose, trehalose and D-xylose, for activity of arginine dihydrolase, lipase (C14), trypsin, $\alpha$-chymotrypsin, $\beta$-galactosidase, $\beta$ glucuronidase, $\alpha$-glucosidase, $\alpha$-mannosidase and $\alpha$-fucosidase and for susceptibility to ampicillin, novobiocin, neomycin, kanamycin, gentamicin and polymyxin B. +, Positive; $\mathrm{w}$, weakly positive; - , negative.

\begin{tabular}{|c|c|c|}
\hline Characteristic & S7-2 ${ }^{\mathrm{T}}$ & $\begin{array}{c}\text { L. litoralis } \\
\text { JCM } 13034^{\mathrm{T}}\end{array}$ \\
\hline Growth with $0.5 \%(\mathrm{w} / \mathrm{v}) \mathrm{NaCl}$ & $+^{*}$ & - \\
\hline \multicolumn{3}{|l|}{ Hydrolysis of: } \\
\hline Casein & + & $-\dagger$ \\
\hline Starch & - & + \\
\hline Tween 80 & + & - \\
\hline \multicolumn{3}{|l|}{ Utilization of: } \\
\hline Cellobiose & + & - \\
\hline Citrate & - & + \\
\hline D-Fructose & - & + \\
\hline D-Galactose & + & - \\
\hline D-Glucose & + & - \\
\hline Pyruvate & - & + \\
\hline Succinate & - & + \\
\hline \multicolumn{3}{|l|}{ Acid production from: } \\
\hline D-Fructose & + & $-\dagger$ \\
\hline Maltose & + & $-\dagger$ \\
\hline D-Ribose & - & $\mathrm{w} \dagger$ \\
\hline Sucrose & + & $-\dagger$ \\
\hline \multicolumn{3}{|l|}{ Enzyme activity (API ZYM) $\dagger$} \\
\hline$N$-Acetyl- $\beta$-glucosaminidase & - & + \\
\hline$\alpha$-Galactosidase & - & + \\
\hline$\beta$-Glucosidase & + & - \\
\hline Esterase (C4) & $\mathrm{w}$ & - \\
\hline Cystine arylamidase & $\mathrm{w}$ & - \\
\hline Valine arylamidase & $\mathrm{w}$ & - \\
\hline Acid phosphatase & + & - \\
\hline Naphthol-AS-BI-phosphohydrolase & + & - \\
\hline \multicolumn{3}{|l|}{ Susceptibility to antibiotics } \\
\hline Cephalothin & - & $+\dagger$ \\
\hline Streptomycin & - & $+\dagger$ \\
\hline Penicillin G & - & $+\dagger$ \\
\hline Tetracycline & - & $+\dagger$ \\
\hline DNA G $+C$ content $(\mathrm{mol} \%)$ & 34.6 & 33.9 \\
\hline
\end{tabular}

${ }^{\star}$ Positive when $\mathrm{Mg}^{2+}$ ions are added.

$\dagger$ Data from this study. 
equipped with a YMC ODS-A $(250 \times 4.6 \mathrm{~mm})$ column. The nucleotides were eluted by a mixture of $0.55 \mathrm{M}$ $\mathrm{NH}_{4} \mathrm{H}_{2} \mathrm{PO}_{4}(\mathrm{pH} 4.0)$ and acetonitrile $(40: 1, \mathrm{v} / \mathrm{v})$, using flow rate of $1 \mathrm{ml} \mathrm{min}^{-1}$ at room temperature and detected by UV absorbance at $270 \mathrm{~nm}$.

Morphological, cultural, physiological and biochemical characteristics of strain $57-2^{\mathrm{T}}$ are given in the species description and in Table 1. The sonicated cell extracts of strain $\mathrm{S} 7-2^{\mathrm{T}}$ showed absorption peak maxima at 450 and $475 \mathrm{~nm}$, indicating the presence of carotenoids (Asker et al., 2007). Flexirubin-type pigments were not produced, as shown by the negative $\mathrm{KOH}$ test. Chromosomal DNA was extracted and purified by the procedure described by Yoon et al. (1996), with the modification that RNase T1 was used in combination with RNase A to minimize contamination by RNA. Amplification of the $16 \mathrm{~S}$ rRNA gene sequence was performed using two universal primers as described previously (Yoon et al., 1998) and the PCR products were purified by using a QIAquick PCR purification kit (Qiagen). Sequencing of the PCR products and phylogenetic analysis were performed as described by Yoon et al. (2003). The almost-complete 16S rRNA gene sequence of strain $\mathrm{S} 7-2^{\mathrm{T}}$ comprised $1436 \mathrm{bp}$, representing approximately $96 \%$ of the Escherichia coli 16S rRNA gene sequence. In the phylogenetic tree constructed using the neighbour-joining algorithm, strain $\mathrm{S} 7-2^{\mathrm{T}}$ joined L. litoralis CF-TF0 $9^{\mathrm{T}}$ with a bootstrap resampling value of $100 \%$ (Fig. 1). The two strains exhibited $95.8 \% 16 \mathrm{~S}$ rRNA gene sequence similarity. The relationship between strain $\mathrm{S} 7-2^{\mathrm{T}}$ and L. litoralis $\mathrm{CF}-\mathrm{TF} 09^{\mathrm{T}}$ was also maintained in the trees constructed using the maximum-likelihood and max- imum-parsimony algorithms (Fig. 1). Strain $\mathrm{S} 7-2^{\mathrm{T}}$ exhibited $16 \mathrm{~S}$ rRNA gene sequence similarity values of less than $91.5 \%$ with the other strains used in the phylogenetic analysis.

The predominant isoprenoid quinone detected in strain S7-2 ${ }^{\mathrm{T}}$ was menaquinone-6 (MK-6) in line with L. litoralis (Choi \& Cho, 2006) and all other members of the family Flavobacteriaceae (Bernardet \& Nakagawa, 2006). The cellular fatty acid profile of strain $\mathrm{S} 7-2^{\mathrm{T}}$ is shown in Table 2, together with that of L. litoralis JCM $13034^{\mathrm{T}}$, which was also analysed in this study. The fatty acid profiles of the two strains were essentially similar, although there were differences in the proportions of some fatty acids. The major fatty acids ( $>10 \%$ of total fatty acids) of strain $\mathrm{S} 7-2^{\mathrm{T}}$ were iso- $\mathrm{C}_{15: 0}(29.6 \%)$ and $\mathrm{C}_{15: 1} \omega 6 \mathrm{c}$ $(10.3 \%)$. The major polar lipids found in strain S7-2 ${ }^{\mathrm{T}}$ and L. litoralis JCM $13034^{\mathrm{T}}$ were phosphatidylethanolamine and three unidentified lipids. Hence, the absence of distinct chemotaxonomic properties between strain S7-2 ${ }^{\mathrm{T}}$ and $L$. litoralis supports the classification of the novel strain into the genus Lutibacter. The DNA G $+\mathrm{C}$ content of strain $\mathrm{S} 7-2^{\mathrm{T}}$ was $34.6 \mathrm{~mol} \%$, a value similar to that reported for L. litoralis JCM $13034^{\mathrm{T}}$.

Strain $\mathrm{S} 7-2^{\mathrm{T}}$ was clearly distinguished from $L$. litoralis by differences in several phenotypic characteristics, including hydrolysis of, utilization of and acid production from several substrates, activity of some enzymes and susceptibility to antibiotics (Table 1). The phylogenetic distinctiveness and the differential phenotypic properties of strain S7- $2^{\mathrm{T}}$ were sufficient to demonstrate that this strain is separate from L. litoralis (Stackebrandt \& Goebel, 1994).

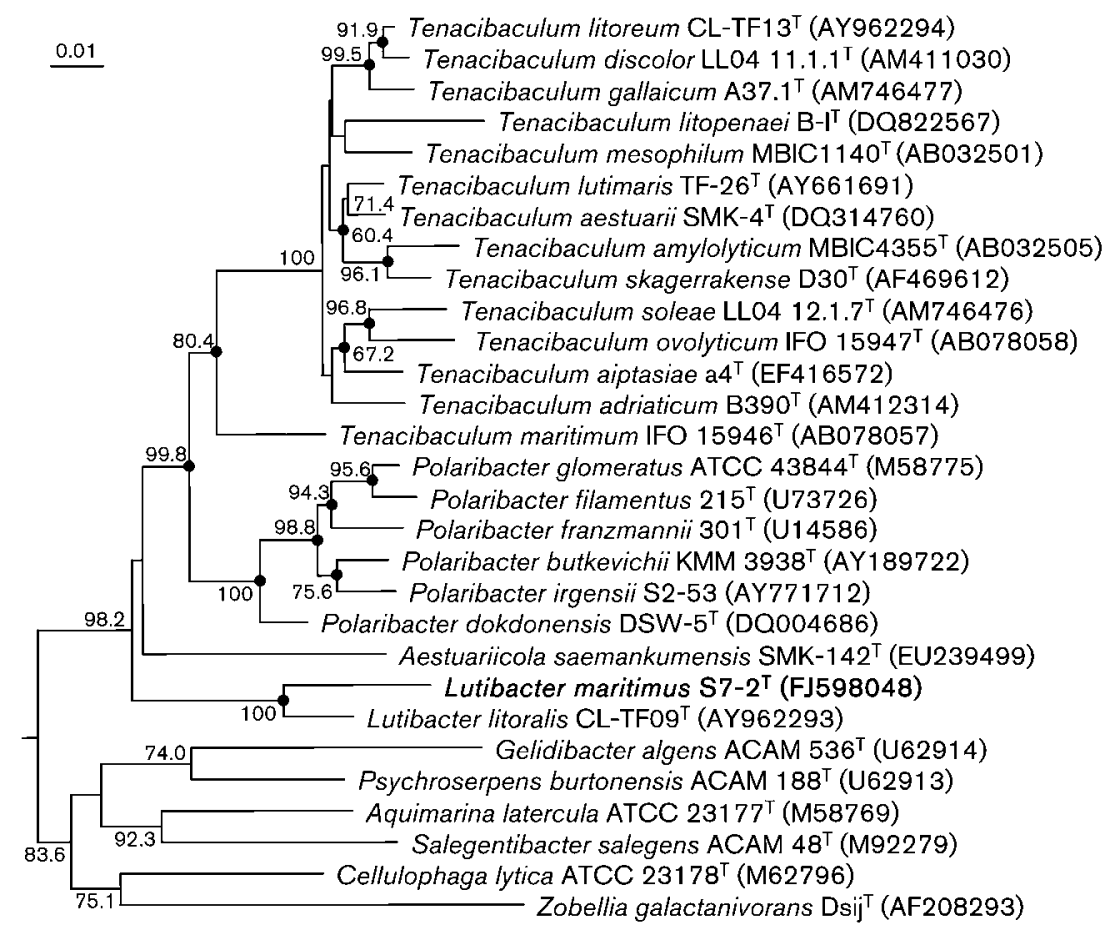

Fig. 1. Neighbour-joining tree based on $16 \mathrm{~S}$ rRNA gene sequences showing the positions of Lutibacter maritimus sp. nov. S7-2 ${ }^{\top}, L$. litoralis CL-TF09 ${ }^{\top}$ and related members of the family Flavobacteriaceae. Bootstrap values (>50\%) based on 1000 resamplings are shown at branch nodes. Filled circles indicate that the corresponding nodes were also recovered in the trees generated with the maximum-likelihood and maximum-parsimony algorithms. Flexibacter flexilis ATCC $23079^{\top}$ (GenBank accession no. M62794) was used as an outgroup (not shown). Bar, 0.01 substitutions per nucleotide position. 
Table 2. Cellular fatty acid compositions of strain $S 7-2^{\top}$ and L. litoralis JCM $13034^{\top}$

Data from this study. Fatty acids that represented $<0.5 \%$ in both strains are omitted. tr, Trace $(<0.5 \%) ;-$, not detected; ECL, equivalent chain-length.

\begin{tabular}{|c|c|c|}
\hline Fatty acid (\%) & $S 7-2^{T}$ & L. litoralis $\mathrm{JCM} 13034^{\mathrm{T}}$ \\
\hline \multicolumn{3}{|c|}{ Straight-chain fatty acid } \\
\hline $\mathrm{C}_{15: 0}$ & 7.2 & 3.3 \\
\hline \multicolumn{3}{|l|}{ Branched fatty acids } \\
\hline iso- $\mathrm{C}_{13: 0}$ & $\operatorname{tr}$ & 1.0 \\
\hline iso- $\mathrm{C}_{14: 0}$ & 3.9 & 6.8 \\
\hline iso- $\mathrm{C}_{15: 0}$ & 29.6 & 17.6 \\
\hline iso- $\mathrm{C}_{16: 0}$ & 2.1 & 1.1 \\
\hline iso- $\mathrm{C}_{15: 1}$ & 3.8 & 6.9 \\
\hline iso- $\mathrm{C}_{16: 1}$ & 3.0 & 3.0 \\
\hline anteiso- $\mathrm{C}_{13: 0}$ & - & 1.1 \\
\hline anteiso- $\mathrm{C}_{15: 0}$ & 6.4 & 17.0 \\
\hline anteiso- $\mathrm{C}_{15: 1}$ & $\operatorname{tr}$ & 1.3 \\
\hline \multicolumn{3}{|c|}{ Unsaturated fatty acids } \\
\hline $\mathrm{C}_{15: 1} \omega 6 c$ & 10.3 & 4.6 \\
\hline $\mathrm{C}_{17: 1} \omega 6 c$ & 0.8 & 0.9 \\
\hline \multicolumn{3}{|l|}{ Hydroxy fatty acids } \\
\hline $\mathrm{C}_{17: 0} 2-\mathrm{OH}$ & 0.6 & 1.0 \\
\hline $\mathrm{C}_{15: 0} 3-\mathrm{OH}$ & 2.3 & 1.1 \\
\hline iso- $\mathrm{C}_{14: 0} 3-\mathrm{OH}$ & 0.6 & 0.9 \\
\hline iso- $\mathrm{C}_{15: 0} 3-\mathrm{OH}$ & 8.4 & 11.6 \\
\hline iso- $\mathrm{C}_{16: 0} 3-\mathrm{OH}$ & 7.1 & 9.6 \\
\hline iso- $\mathrm{C}_{17: 0} 3-\mathrm{OH}$ & 3.9 & 2.0 \\
\hline \multicolumn{3}{|l|}{ Summed features ${ }^{\star}$} \\
\hline 1 & 3.1 & 1.8 \\
\hline 3 & 0.6 & 1.3 \\
\hline \multicolumn{3}{|l|}{ Unknown fatty acids } \\
\hline ECL 11.543 & 1.5 & 3.3 \\
\hline ECL 13.565 & 1.4 & 0.9 \\
\hline
\end{tabular}

*Summed features represent two or three fatty acids that cannot be separated by the Microbial Identification System. Summed feature 1 consisted of iso- $\mathrm{C}_{15: 1}$ and/or $\mathrm{C}_{13: 0}$ 3-OH. Summed feature 3 consisted of $\mathrm{C}_{16: 1} \omega 7 c$ and/or iso- $\mathrm{C}_{15: 0} 2-\mathrm{OH}$.

Therefore, on the basis of the phenotypic and phylogenetic data, strain $\mathrm{S} 7-2^{\mathrm{T}}$ is considered to represent a novel species of the genus Lutibacter, for which the name Lutibacter maritimus sp. nov. is proposed.

\section{Description of Lutibacter maritimus sp. nov.}

Lutibacter maritimus (ma.ri'ti.mus. L. masc. adj. maritimus of the sea, marine, maritime).

Cells are Gram-staining-negative, aerobic, non-flagellated, non-gliding and rod-shaped, $0.3-0.8 \mu \mathrm{m}$ in diameter and $1.0-5.0 \mu \mathrm{m}$ in length. Spherical cells are not found. Colonies on MA are circular with entire margins, convex and yellow in colour. Carotenoid pigments are produced, but flexirubin-type pigments are not produced. Growth occurs at 4 and $37{ }^{\circ} \mathrm{C}$ (optimum $25-30{ }^{\circ} \mathrm{C}$ ), but not at
$40{ }^{\circ} \mathrm{C}$. Growth occurs at $\mathrm{pH} 5.0$ (optimum $\mathrm{pH}$ 7.0-8.0), but not at $\mathrm{pH} 4.5$. Growth occurs in the presence of $0.5-$ $5.0 \%(\mathrm{w} / \mathrm{v}) \mathrm{NaCl}$ (optimum approximately $2.0 \%(\mathrm{w} / \mathrm{v})$ $\mathrm{NaCl}) . \mathrm{Mg}^{2+}$ ions are required for growth. Maltose is utilized as sole carbon and energy source, but L-arabinose, L-glutamate, D-mannose, sucrose, trehalose, D-xylose, acetate, benzoate, L-malate, salicin and formate are not. The predominant menaquinone is MK-6. The major polar lipids are phosphatidylethanolamine and three unidentified lipids. The major cellular fatty acids $(>10 \%$ of total fatty acids) are iso- $\mathrm{C}_{15: 0}$ and $\mathrm{C}_{15: 1} \omega 6 c$. Other phenotypic characteristics are given in Table 1.

The type strain, $\mathrm{S} 7-2^{\mathrm{T}}\left(=\right.$ KCTC $22635^{\mathrm{T}}=$ CCUG $\left.57524^{\mathrm{T}}\right)$, was isolated from a tidal flat sediment at Saemankum on the west coast of Korea. The DNA G $+\mathrm{C}$ content of the type strain is $34.6 \mathrm{~mol} \%$ (determined by HPLC).

\section{Acknowledgements}

This work was supported by the 21C Frontier Program of Microbial Genomics and Applications (grant MG05-0401-2-0) from the Ministry of Education, Science and Technology (MEST) of the Republic of Korea.

\section{References}

Asker, D., Beppu, T. \& Ueda, K. (2007). Zeaxanthinibacter enoshimensis gen. nov., sp. nov., a novel zeaxanthin-producing marine bacterium of the family Flavobacteriaceae, isolated from seawater off Enoshima Island, Japan. Int J Syst Evol Microbiol 57, 837843.

Baumann, P. \& Baumann, L. (1981). The marine Gram-negative eubacteria: genera Photobacterium, Beneckea, Alteromonas, Pseudomonas, and Alcaligenes. In The Prokaryotes, pp. 1302-1331. Edited by M. P. Starr, H. Stolp, H. G. Trüper, A. Balows \& H. G. Schlegel. Berlin: Springer.

Bernardet, J.-F. \& Nakagawa, Y. (2006). An introduction to the family Flavobacteriaceae. In The Prokaryotes: A Handbook on the Biology of Bacteria, 3rd edn, vol. 7, pp. 455-480. Edited by M. Dworkin, S. Falkow, E. Rosenberg, K.-H. Schleifer \& E. Stackebrandt. New York: Springer.

Bernardet, J.-F., Segers, P., Vancanneyt, M., Berthe, F., Kersters, K. \& Vandamme, P. (1996). Cutting a Gordian knot: emended classification and description of the genus Flavobacterium, emended description of the family Flavobacteriaceae, and proposal of Flavobacterium hydatis nom. nov. (basonym, Cytophaga aquatilis Strohl and Tait 1978). Int J Syst Bacteriol 46, 128-148.

Bernardet, J.-F., Nakagawa, Y. \& Holmes, B. (2002). Proposed minimal standards for describing new taxa of the family Flavobacteriaceae and emended description of the family. Int J Syst Evol Microbiol 52, 1049-1070.

Bowman, J. P. (2000). Description of Cellulophaga algicola sp. nov., isolated from the surfaces of Antarctic algae, and reclassification of Cytophaga uliginosa (ZoBell and Upham 1944) Reichenbach 1989 as Cellulophaga uliginosa comb. nov. Int J Syst Evol Microbiol 50, 18611868.

Bruns, A., Rohde, M. \& Berthe-Corti, L. (2001). Muricauda ruestringensis gen. nov., sp. nov., a facultatively anaerobic, appendaged bacterium from German North Sea intertidal sediment. Int $J$ Syst Evol Microbiol 51, 1997-2006. 
Choi, D. H. \& Cho, B. C. (2006). Lutibacter litoralis gen. nov., sp. nov., a marine bacterium of the family Flavobacteriaceae isolated from tidal flat sediment. Int J Syst Evol Microbiol 56, 771-776.

Cohen-Bazire, G., Sistrom, W. R. \& Stanier, R. Y. (1957). Kinetic studies of pigment synthesis by nonsulfur purple bacteria. J Cell Comp Physiol 49, 25-68.

Cowan, S. T. \& Steel, K. J. (1965). Manual for the Identification of Medical Bacteria. London: Cambridge University Press.

Komagata, K. \& Suzuki, K. (1987). Lipid and cell-wall analysis in bacterial systematics. Methods Microbiol 19, 161-207.

Lányí, B. (1987). Classical and rapid identification methods for medically important bacteria. Methods Microbiol 19, 1-67.

Leifson, E. (1963). Determination of carbohydrate metabolism of marine bacteria. J Bacteriol 85, 1183-1184.

Minnikin, D. E., O'Donnell, A. G., Goodfellow, M., Alderson, G., Athalye, M., Schaal, A. \& Parlett, J. H. (1984). An integrated procedure for the extraction of bacterial isoprenoid quinones and polar lipids. J Microbiol Methods 2, 233-241.

Reichenbach, H. (1992). The order Cytophagales. In The Prokaryotes, 2nd edn, vol. 4, pp. 3631-3675. Edited by A. Balows, H. G. Trüper, M. Dworkin, W. Harder \& K. H. Schleifer. New York: Springer.

Sasser, M. (1990). Identification of bacteria by gas chromatography of cellular fatty acids, MIDI Technical Note 101. Newark, DE: MIDI Inc.
Stackebrandt, E. \& Goebel, B. M. (1994). Taxonomic note: a place for DNA-DNA reassociation and $16 \mathrm{~S}$ rRNA sequence analysis in the present species definition in bacteriology. Int J Syst Bacteriol 44, 846849.

Staley, J. T. (1968). Prosthecomicrobium and Ancalomicrobium: new prosthecate freshwater bacteria. J Bacteriol 95, 1921-1942.

Tamaoka, J. \& Komagata, K. (1984). Determination of DNA base composition by reversed-phase high-performance liquid chromatography. FEMS Microbiol Lett 25, 125-128.

Teather, R. M. \& Wood, P. J. (1982). Use of Congo red-polysaccharide interactions in enumeration and characterization of cellulolytic bacteria from the bovine rumen. Appl Environ Microbiol 43, $777-780$.

Yoon, J.-H., Kim, H., Kim, S.-B., Kim, H.-J., Kim, W. Y., Lee, S. T., Goodfellow, M. \& Park, Y.-H. (1996). Identification of Saccharomonospora strains by the use of genomic DNA fragments and rRNA gene probes. Int J Syst Bacteriol 46, 502-505.

Yoon, J.-H., Lee, S. T. \& Park, Y.-H. (1998). Inter- and intraspecific phylogenetic analysis of the genus Nocardioides and related taxa based on 16S rDNA sequences. Int J Syst Bacteriol 48, 187-194.

Yoon, J.-H., Kim, I.-G., Shin, D.-Y., Kang, K. H. \& Park, Y.-H. (2003). Microbulbifer salipaludis sp. nov., a moderate halophile isolated from a Korean salt marsh. Int J Syst Evol Microbiol 53, 53-57. 